\title{
Introduction: Enquiries into Contemporary Ritual Landscapes
}

\section{Virtanen, Pirjo Kristiina}

2017

Virtanen , P K , Lundell , E A-M \& Honkasalo , L M-L 2017 , ' Introduction: Enquiries into Contemporary Ritual Landscapes ' , Journal of ethnology and folkloristics , vol. 11 , no. 1 , pÿpp. 5 17. . https://doi.org/10.1515/jef-2017-0002

http://hdl.handle.net/10138/232228

https://doi.org/10.1515/jef-2017-0002

cc_by_nc_nd

publishedVersion

Downloaded from Helda, University of Helsinki institutional repository.

This is an electronic reprint of the original article.

This reprint may differ from the original in pagination and typographic detail.

Please cite the original version. 


\title{
IN TRODUCTION: ENQUIRIES INTO CONTEMPORARY RITUAL LANDSCAPES
}

\author{
PIRJO KRISTIINA VIRTANEN \\ Assistant professor \\ Indigenous studies \\ University of Helsinki \\ Unioninkatu 40, P.O. Box 24 \\ 00014 University of Helsinki, Finland \\ e-mail: pirjo.virtanen@helsinki.fi \\ ELEONORA A. LUNDELL \\ MA, PhD Student \\ Department of World Cultures \\ University of Helsinki \\ Unioninkatu 38 A, P.O. Box 59 \\ 00014 University of Helsinki, Finland \\ e-mail: eleonora.lundell@gmail.com
MARJA-LIISA HONKASALO
Professor \\ Center for the Study of Culture and Health \\ University of Turku \\ Kaivokatu 12 \\ 20014 University of Turku, Finland \\ e-mail: marja-liisa.honkasalo@utu.fi
}

\begin{abstract}
'Landscape' and 'ritual' have been largely discussed in the social and human sciences, although their inter-relatedness has gained little scholarly attention. Drawing on earlier studies of ritual and landscape, as well as the authors' own ethnographic works, 'ritual landscape' is suggested here as a useful analytical tool with which to understand how landscapes are produced, and how they, in their turn, produce certain types of being. 'Ritual landscape' recognises different modalities of agency, power-relation, knowledge, emotion, and movement. The article* shows how the subjectivity of other-than-human beings such as ancestors, earth
\end{abstract}

* Our research has been funded by the Research Funds of the University of Helsinki and the Academy of Finland (project entitled Mind and the Other: An Interdisciplinary Study on the Interactions of Multiple Realities, SA 266573). 
formations, land, animals, plants and, in general, materiality of ritual contexts, shape landscapes. We argue that ways of perceiving landscape includes a number of material and immaterial aspects indicated by ways of moving through landscapes and interacting with different human and non-human subjects that come to inhabit the world, creating relations and producing agentive ensembles and complexes.

KEYWORDS: ritual landscape $\bullet$ non-human agency $\bullet$ materiality $\bullet$ immateriality $\bullet$ belonging $\bullet$ relationality

'Ritual landscape' as a concept emerged in archaeology in the 1980s to conceptualise sacred archaeological complexes where the artefacts found are mainly ceremonial, and where material evidence of other human activity is absent or sparse (Robb 1998). A variety of ontological notions involved in ritual practice affect how landscapes are created, transformed, perceived, and experienced, both in urban and rural areas, and from this understanding the idea of landscape as produced as a consequence of the thought and values related to so-called sacred or social orders has emerged (Morphy 1991; Moore 2004).

This special issue invites authors to discuss ritual landscape through the medium of contemporary ethnography. Our questions initiate exploration in two directions: firstly, the ways in which ritual (re)produces and organises landscape and the kinds of ritual agency that intertwine with this process. How is landscape perceived in the ritual process? What are the methods of creating ritual landscapes? This special issue examines specific knowledge, sounds, smells, and visual elements as ways of engaging with certain places and spaces or thinking about its human and non-human actors. What do these factors indicate?

The second direction attends to how landscape, in its turn, shapes and modifies ritual. The ethnographies presented in this special issue discuss the different ideas relating to subjectivity, the personhood of spirits, objects, earth formations, land, ancestors, plants, and animals that act in ritual contexts in relation to landscape. We especially focus on interactions between human and non-human actors in the making of ritual landscapes. Thus, we not only address the acts of humans, but also the role of nonhumans as we consider their agency in terms of materiality and movement crucial in the production of ritual landscapes.

We also ask how ritual landscapes are embedded and produced in politics and economics and how these, in their turn, produce landscapes. And how do specific historicities shape ritual landscapes? Furthermore, what can we say about landscapes in places where different religious ontologies coexist and merge, such as in the context of the urban areas? These landscapes can even become battlefields when different actors aim to use the same places for their ritual purposes. Indeed, landscapes can have overlapping meanings in terms of lived space, cognitive schemas, sensorial emphases, and religious socio-cosmologies.

Taking this into consideration, the articles look at the ways contemporary ritual landscapes are employed in Western Siberia (among the Khanty), among Buddhist initiates in Burma, in the course of making community-based, documentary, video art in indigenous Mexico (among the Wixárika), during the weekly rituals performed at the Israeli-Palestinian Wall on the West Bank, and in global digital mediascapes. On the one 
hand, rituals are addressed in everyday settings as ritualisation, while on the other they are also considered as set apart from everyday life.

\section{LANDSCAPES PRODUCED BY HUMANS AND LANDSCAPE PRODUCING HUMANS}

In asking these landscape-related questions we join a long discussion in anthropology and philosophy about space and spatiality. The books A Phenomenology of Landscape: Places, Paths, and Monuments by Christopher Tilley (1994) and Anthropology of Landscape: Perspectives on Place and Space by Eric Hirsch and Michael O'Hanlon (1995) have been seminal in anthropological studies of landscape. Both discussed lived engagements with surroundings through embodiment, as well as collective and personal histories inscribed in the landscape. Following Hirsch, Philippe Descola (2013) has presented the idea of landscape as transfiguration, which effectively encapsulates how landscape is both material mediation, in situ, and includes sensory-aesthetic elements, in visu. Humans fashion the landscape via transfiguration. It is a process of actualisation because by acts, such as creating swidden gardens, people produce iconic elements that are in fact signs standing for something else. This is a cultural process similar to Hirsch's and O'Hanlon's idea (1995) as it underlines individual management, tastes, and differences although Descola emphasises the role that humans play in activating indexical relations between actors, such as regarding plants as children who are cared for and treated as kin by their caretakers. A swidden garden can thus be an ecosystem transfigured by people.

Scholars have made use of a variety of spatial concepts, such as place, space, and landscape. A methodological dividing line runs between assumptions of the primacy of 'objective' place - or locus - that exists independently, without or before our perception or agency, and that of space as lived, remembered, and engaged. The relationship between ritual and space - or landscape - has been portrayed from both angles. Research on holy places with ceremonial rituals can serve as an example of the first: what is primary is the place that is 'there', changeless and immutable. The second has been debated by Doreen Massey (1994; 2005), Edward Casey (1993; 1997), Tim Ingold (2000; 2009), and Peter Wynn Kirby (2009), among others; the writers for this special issue take the same approach when we address landscape.

Place, space, and landscape have been portrayed as perspectival, shaped by the views - from various positions - of those who participated in shaping it. Landscape is not only for seeing; it also provides those agents who live and dwell within it elements for signifying and meaning making (Casey 1993). Ethnography is a key to understanding different senses of place, as people have different engagements with the world around them. It has also been argued that for the one who dwells and sees, or participates, the relationship is mutual and intersubjective: space - and landscape - affects actors, and therefore some places may feel more homelike. Both landscape and its participants are in history and memory, which they have created together. Yet in addition to landscape as lived, Kirsten Hastrup (1998) - examining Iceland and its people - stresses discursive relationships with the landscape, for instance with land and water, which make people conceptualise themselves as certain types of being. Therefore, landscape also shapes humans differently, as well as their histories. 
The relation between landscape, history, and myth has been discussed by Robin Wright (2013), among others. According to Claude Lévi-Strauss (1958), myths express oppositions, but also resolve them. Different opposing structures, such as this world and the other world, and their further various levels, can be engaged with in ritual space, as well as other incompatible aspects of human lives, including gender and age cohort (Houseman and Severi 1998). Myths and oral histories can thereby create ritual landscapes. This special issue opens with an article by Art Leete on the structural space of the Khanty, which they divide between the living and the dead, the Upper and Lower part of the world, both of which include further different levels. Rituals taking place in Khanty landscape, shared by different actors, such as Khanty people, reindeer, and gods, unite the different levels. Leete's article discusses ways of seeing the sacred topography, so prominent in the studies of vernacular religion, as something constant and 'out there'. Yet he also demonstrates how the dimensions of the world, and consequently its spatial conceptualisations, alter according to modalities of the ritual process.

Lea and Pekka Kantonen then describe how the Wixárika people in Mexico, during their pilgrimage, walk in the footsteps of their ancestors; spatial organisation of the landscape, therefore, is crucially founded in ancestral time and the cardinal directions. This is similar to the practices of many other indigenous peoples. Landscape can operate as a mnemonic device with certain places becoming iconic because they stand for past events and the acts of past generations. Fernando Santos-Granero (1998), who has worked in Peru, has used the term topographic writing to refer to the way in which the oral history of the Yanesha people is expressed in certain landscape features and retold by community members. For the Yanesha, living in the Peruvian Amazon, specific geographical landmarks and places (topographs) are associated with past events that are units of longer narratives. Landscape can obtain its meaningful place as a result of ancestors moving through it and living in it, thereby producing it (see, for example, Morphy 1991; Pérez 2012 on the Hopi). The Kantonens' article adds to this discussion by focusing on transformations in ritual landscapes, arguing that today local school and museum projects also make the Wixárika move around. The Kantonens suggest that the ancestors are now deeply intertwined with these new ritual spaces and ritual acts related to the school and local museum.

\section{RITUAL THROUGH LANDSCAPE}

Rituals have been much debated in anthropology, religious studies, linguistics, sociology, and many other fields of the social sciences, although there have also been periods when the concept of ritual has been avoided or has not attracted attention as a category. Ritual can be a tool because it can serve to reorganise social context. It has its functional aspects, but it can also be approached from ontological perspectives on beings and being. Aesthetics also play a crucial role in the formal aspects of rituals. Lastly, rituals have a pragmatic level, as rituals say something about actions and interactions in the course of events. These issues between ritual and landscape have remained largely unexplored.

Since Gregory Bateson's (1972) classic study, Steps to the Ecology of Mind, the relationbuilding character of ritual has been a much discussed topic. The ritual that enacts relationships, and the relationality of rituals, have also been addressed by Michael House- 
man (2006), who has emphasised that exceptional relationships reorganise into a totality, for instance between ritual participants orchestrated by emotionally meaningful ritual acts. We have been interested in how these repetitive relationships between actors are activated towards landscape, creating a totality. The activating of relationships as management of landscape can be done by moving through and organising the space, the use of speech in certain places, and by addressing different aspects of landscape, as pointed out by Tilley (1994) in his phenomenological studies of movement, body, and landscape.

As rituals have been considered ways to relate and as ways to establish relations between ritual participants, they often also actualise a diversity of non-humans inhabiting the world. Landscape can configure and attune these relationships in different ways and several methods of configuration are addressed in the articles that follow. For example, different visualisation skills may be essential in order to master methods of transfiguration (Virtanen 2011, see also Virtanen and Saunaluoma forthcoming). Pirjo Kristiina Virtanen (2011) has suggested that precolonial geometric earthworks in south-western Amazonia are closely related to the practices of dreaming and having visions, for which several indigenous groups in lowland South America learn and train from an early age. The study of geometric earthworks in lowland South America, which has altered outsiders' perceptions of Pre-Columbian societies in the region, essentially materialise the world of other-than-human beings that has been collectively addressed, interacted with and shared during rituals. The ways of moving designed by the places of certain non-humans is also central among several Amazonian indigenous groups (Virtanen 2015; see also Myers 2013 on Australia).

The material representations are in fact doors to the world of spirits, which can also be understood as macrocosmos. People can connect to landscape, as it can be used as a map for participants in rituals who feel special relationships between here and what is imagined. Landscapes can thus have indexical connections and reify something that is merely indicated. Christopher Ball (2014), for example, in his work on dicentisation as semiotic action has looked at different worlds of perception, referring to ethnographic examples by other researchers. In one of these, referring to the work of Allan Grapard, Ball showed how Japanese mountain landscapes formed by Buddhist practitioners could, through ascetic practices of perception, allow one to see beyond them and connect with the truth of the teachings of Buddha.

Ingold (1993: 152-153) has stated that the landscape tells a story:

To perceive the landscape is therefore to carry out an act of remembrance, and remembering is not so much a matter of calling up an internal image, stored in the mind, as engaging perceptually with an environment that is itself pregnant with the past.

Land can even have its own songs and sounds, as pointed out by Fred Myers (2013) in his study with the Warlpiri in Australia in which he focused on how they learn their ties to the land and its beings in social relations with others. The temporality of landscape is social, as landscape can be created by certain activities, auditory emphases, movements, and paths that give specific rhythms to landscape, and finally its form (Ingold 1993; see also Tilley 1994). Moreover, temporality is present in the landscape in the sense that the past actions of humans and non-humans are embedded in it. Interaction with the land- 
scape is, however, contextual engagement, and therefore landscape can be perceived and related to differently at different times - and when it comes to ritual behaviour, there are different rules of engagement.

In rituals specific knowledge is acted upon that often is not widely shared or official. Ritual knowledge is frequently gained through personal experiences that are collectively shared amongst those at the same level, while ritual acts shed light on specific features of the world. The relationship between ritual and structure has been debated by a number of scholars, with Victor Turner (1967) prominent among them, and it has been argued that rituals are "vehicles for all forms of authority"; at the same time their socially transformative potential has also been acknowledged (Kelly and Kaplan 1990: 141). Thus in this special issue we address questions of authority, discussing how both humans and non-humans can act as authority and how this is reflected in ritual landscapes. Humans such as ritual leaders have greater control over the relationships created during ritual, but non-human agencies also play a crucial role in shaping both ritual forms and how landscape is produced and managed through interactions between different actors. In ritual landscapes other-than-human beings can be constantly 'acting back', as the world is populated by different types of being who are created through the relations between other beings. Kantonens' article also discusses the active role of the spirits in controlling and affecting the contemporary use of the camera, which they as researchers brought to the ritual landscape.

Non-human agents can be ancestors who are frequently consulted in a variety of healing rituals. The ancestor spirits are thought of as living beings, and may be activated during rituals. They are often also authorities on ritual who play prominent roles in ceremonial consultations, while actors in the healing ceremonies can also become possessed by them (see also Obeyesekere 1981; Lambek 1999). Kantonens' and Leete's articles underline the intimate ties to ancestors and emotions generated by mythical images in an ontological thinking shared across the generations.

It has been suggested that rituals can deal with existing emotions or create new ones, something that has been a much debated theme in anthropology (see Bateson 1963; Metcalf 1991). In his Elementary Forms of Religious Life Émile Durkheim (1947 [1912]) emphasises the enormous power of ritual to produce effervescence. What ritual does emotionally is to energise people and make them feel larger than themselves. According to François Berthomé and Michael Houseman (2010), connections between ritual and emotion can be considered from two angles: as emergent properties and integral components of the ritual process, and as relational, as sensate, qualities of a relationship. Bereavement rituals include both: they are capable of creating sadness, sorrow, pain, and tears for the ritual participants. Emerging emotions and intense relationships are badly needed in the ritual context (for example, Caraveli-Chaves 1980). Bereavement rituals include emotions in landscape - and belonging - in different ways because the ritual person, the deceased, is being detached from the present landscape in order to travel to the place of the ancestors. Healing rituals are emotionally loaded, and in extreme bodily states, such as possession, shared emotions between the participants, and even the generations, coordinate and result in what is called the efficacy of the ritual practice (Obeyesekere 1981).

This volume contains articles in which lived space is a core issue. Bénédicte Brac de la Perrière's article looks at individual embodiments of Buddha's teachings and how 
initiations in Buddhist monasticism, Buddhist esotericism and spirit worship distinguish categories of actions according to their religiosity in a Buddhist landscape. The article by Kantonens indicates that devotion and feeling responsible are crucial emotional responses among the Wixárika. Johanna Sumiala's article addresses mourning in a digital ritual landscape, a mode of sharing emotions that is becoming increasingly prevalent in the contemporary world.

\section{MATERIALITY OF NON-HUMANS, AND ONTOLOGICAL MODALITIES, IN RITUAL LANDSCAPES}

This special issue, through different ethnographic examples, also mirrors the diversity of ways in which people relate to the materiality of landscapes in ritual contexts. One of our aims is to argue that the materiality of landscapes cannot be separated from people. Following recent cross-disciplinary approaches known as the new materialism, posthumanism, and the ontological turn in anthropology, we emphasise the importance of non-human agency in the processes of producing, interpreting, and perceiving contemporary ritual landscapes. Among others, we take the groupings produced by the interactions of humans and certain non-humans to be "biosocial assemblages", a term that Ingold and Gisli Pálsson (2013) have suggested for relations between humans and other life forms. We also look at the existence, grounded in materiality of experience (see Coole and Frost 2010). Thus, looking at how people relate to and interact with material objects within diverse ritual scenarios may deepen our understanding of different virtualities and actualities of lived experiences. By giving emphasis to materiality in ritual landscapes we want to stress that analysing the encounters of people and objects within different rituals may open up new perspectives on how things (material and immaterial, human and non-human) participate in the making of everyday lives in the contemporary world.

The role of sacrifice is crucial in many rituals (see Leete's article) and has been regarded as a core issue by scholars since the works of Durkheim (1947 [1912]) and Henry Hubert and Marcel Mauss (1964 [1899]). According to Victor Turner (1977), sacrifice is a quintessential process as it is necessary for the successful consultation of the oracle or divinity, or for an answer. In the ritual context, the landscape of sacrifice is one of mediation between this world and the otherworld. Of all sacrifices in ritual processes, blood sacrifice is the most powerful in protecting and securing the promise of human life in the face of human malice or evil from the external world. Based on exchange between the sacred and the profane, on a gift to the divine beings in order to get effective protection, animal sacrifice is performed by order of the respective god from whom a response is expected. The question of sacrifice as a material object playing a central role in the ritual can be conceptualised as an assemblage, and thus a part of the actor network that is widely in motion in society beyond the ritual process. Drawing on Bruno Latour's (2005) actor-network theory, a methodology for understanding society as consisting of networks assembling humans, non-humans and technologies, sacrifice becomes meaningful through an assemblage with other actors: material, immaterial, and human. What is social for Latour is the network of associations between movement, displacement, transformation, translation, and enrolment (ibid.: 64-65). In this context, 
even sacrifice can be analysed as an actor par exellence that induces the other actors to create new assemblages and monetary associations, which gather together ritual actors into new shapes. This kind of an analysis deserves to be carried out. We think it can put forward new associations between different societal networks, and is also important for comprehending ritual sacrifice in its full meaning.

Sacrifice is also a necessary actor in the healing rituals, which have a specific landscape consisting of colour, movement, and smell (Taussig 2009). In her study (in the context of West African healing ritual) Marja-Liisa Honkasalo (2016) analyses the efficacy of ritual by examining a variety of different healing practices. For the purpose of efficacy, everything that is usable seems to matter when people deal with sick children, family members, or neighbours. In the challenging situation of poverty and hunger in the developing countries people demonstrate unbelievable creativity in shaping ritual objects out of pieces of what we call trash - metal, rope, chains, or calabash - and in planning dance, music, clothes, and instruments. In her ethnography, in what she calls "ritual plenitude", Honkasalo follows ritual practices in a diasporic setting. The same creativity of building ritual practices continues in an unexpected synchrony with transnational resources. This is also what they do as 'missionaries' as the people of West African origin call themselves as immigrants in Northern European cities.

Human-non-human relations in a ritual landscape simultaneously produce and are produced by different forms of power relation: socio-political, religious, economic, and so forth. In fact the understanding of the ontological status and effects of things in different ritual landscapes brings us closer to contextual modes of power. For instance, one manifestation of the violent conflict between Afro-Brazilian religions and Neo-Pentecostalism in Brazil is the appropriation of the ritual objects of Afro-Brazilian religions (such as sea salt, roses, the arruda herb, religious bodies) in neo-Pentecostal ceremony carried out in hundreds of Iurd churches (Igreja Universal de Reino de Deus) in Southeast Brazilian metropolitan areas (Benedito 2006; Lundell 2010). The neo-Pentecostal logic in the ritual of exorcism (aimed at freeing people from the influence of Afro-Brazilian spirits) is based on knowledge of the agency of these specific material things. This particular church is one of the most lucrative business corporations in Brazil and, like many big Pentecostal churches in the country, participates strongly in national politics. Thus, the analytical emphasis on the materiality of religious experience within ritual landscapes may enable new perspectives on, and increased understanding of, for example, the considerable societal changes due to Pentecostal expansion in contemporary Brazil.

Focusing on materiality within ritual landscapes benefits many of the ideas presented recently by scholars of the 'ontological' approach in anthropology (see Henare et al. 2007). Some studies, especially those concerning Afro-Brazilian (Goldman 2011; Halloy 2013; Sansi 2013) and Cuban religious worlds (Holbraad 2011; 2012; Blanes and Espírito Santo 2014) have criticised the 'representationalist' tendency within earlier studies of religious rituals. In other words, these studies have shown that the Cartesian dualistic divisions between nature and culture, material and immaterial do not always correspond with the knowledge of the ritual participants, yet this is the model that has been largely used as the foundation for the theoretical concepts in analysing religious phenomena such as 'spirit', 'god', 'religion', 'sacred', and 'profane'. Moreover, the ontological critique has suggested that the notion and experience of subjectivity, agency, and materiality can emerge through totally different ontological modalities (see 
Holbraad 2012). For example, in Afro-Brazilian (religious) experience different things and beings are ontologically connected with each other through the notions of axé (a single force that all things in the world are modulations of), orixás (vital forces of nature which manifest in people and in things, such as in elements of nature, colours, gestures) and spirit entities (portug. entidade; ancestor beings which manifest and materialise in people and things). This specific "vitalism" (Goldman 2011: 116; Lundell 2016: 53-59) penetrates the ritual landscape and its human and non-human actors in such a way that in a ritual work of Umbanda and Candomblé the material objects can become subjects (in processes of knowledge production and healing), while people are seen as objects or tools of the spiritual work carried out by the non-human spirit entities (entidade, guia) through materialisation in ritualised bodies. Furthermore, the ontological status and agency of ritual objects (including different material things as well as the human body) in rituals carried out in the Umbanda houses of São Paulo, is not merely representative but can be thought of as primarily transformative and re-configurative (Lundell 2016).

The work of Latour especially has brought new perspectives to life through things. In this special issue Elisa Farinacci presents a Latourian theory of assemblages and analyses the formations of a specific ritual landscape in a well known conflict zone: the Christian shrine known as Our Lady of the Wall, located in the wall built by the Israeli government to assure the safety of Israeli citizens from Palestinian occupation. Farinacci's ethnography demonstrates that the ritual landscape emerges as a process of entanglement with the wall, in which, in opposition to its political existence, Roman Catholic nuns decided to found a shrine with an icon of the Virgin Mary.

Using the actor-network approach Farinacci argues that the ritual as an assemblage develops its agency through an interplay between a vast number of human and nonhuman actants. In addition, a spatial concept - the border/boundary - is of importance in her analysis. The idea of a boundary, the Wall, provides another new view on the question of the relationship between landscape and ritual. What the border does is to separate two groups of ritual participants, leaving one on either side of it, separating agency and splitting it into two. The built border, a space, separates not only people with different religious backgrounds but also actuality and virtuality, both of which are necessary dimensions of a chain of action: of play, phantasy, and ritual (Bateson 1972). Ritual, however, is able to bring them together into a landscape where both - virtuality and actuality - exist simultaneously (Latour 2012).

\section{ALTERING RITUAL LANDSCAPES}

When thinking about ritual landscapes we must also pay attention to the question of transformation. Thus, as we have seen, changes (political, cultural, religious, social, and so forth) constantly affect the intersubjective relations between the actors and assemblages that produce ritual landscapes. Leete's article in this special issue provides an interesting ethnographic perspective by showing how changes in dwelling and subsistence effect changes in ritual landscapes. His study demonstrates that among the Khanty the rituals of death and rituals of reindeer offerings are carried out according to different, seemingly contradictory, topographic orientations - mythical and non-mythical. Thus, as Leete shows, the notion of landscapes can also be flexible because people, 
as well as landscapes, experience constant changes, and controversies of orientation towards the ritual landscape may emerge. Leete suggests that this controversy (which for the Khanty is no controversy) indicates that certain patterns, or the contextual logic of change itself, can be detected within specific ritual landscapes that are spaces of meaning-making where different knowledges and agency enact in flexible ways.

Finally, thinking about ritual landscapes in the age of digitisation and the digital mediascape, Johanna Sumiala's article makes an interesting ethnographic contribution to this special issue by discussing the ritualisation of death in the virtual landscape of social media. Sumiala analyses the ritual mourning within the digital mediascapes of people killed in the Charlie Hebdo attacks. Following Arjun Appadurai's definition, Sumiala understands that mediascape refers both to the "technological capabilities that produce and disseminate information" as well as to "the images of the world created by these media" (p. 112). As Sumiala states, the division between the 'virtual' and the 'actual' world is very challenging as the physical and the digital are tightly intertwined in events such as the Charlie Hebdo tragedy. Including the digital world in the analysis of ritual is highly important as the internet and the expansion of social media have enabled new forms of sociality (ritual and non-ritual) in the contemporary world by both breaking and creating boundaries between people interacting, producing knowledge, and exercising agency within the global society. In contemporary ritual landscapes, where the virtual 'digital' is not even in fact separate from the 'actual' we could perhaps develop further the idea of how the materiality of these technologies and images, which form the mediascape, according to Appadurai and Sumiala, are internalised parts of our new subject positions in the 'glocal' totalities in which we now live.

Ritual as a concept has been criticised in studies of modern, plural societies. In sociological studies, it has sometimes been considered an old-fashioned concept that applies only to non-modern societies. Anthropologist Joel Robbins has developed two important elements to this discussion, however: first, based on his studies of global Pentecostal movements, he writes about ritual as a mode of sociality (2009), emphasising the enormous institution-building capacity that the movement has, and noting that it is precisely the fundamental role of ritual that makes it possible. The Pentecostals make use of the association-building capacity of ritual and operationalise the understanding that social life is dense with rituals the performance of which may lead to success. Second, Robbins and Sumiala (2016) present another theme that makes ritual important in modern social life by emphasising the role of ritual in modern society as being both private and public. Ritual produces intimacy, which is an extremely important issue in modern, globalising society with its increasing exclusion, marginalisation, and failing sense of belonging. In this context, through current social media and the politics of representation more generally, the ritual landscape can also become larger and shared worldwide.

Meanwhile, as the articles in this issue demonstrate, the new ritual landscapes that emerge make people connect in novel ways, offering and promoting a sense of belonging. In contemporary studies of ritual we find that emotions, belonging and relationality are important themes, especially in the context of post-secular movements, as well as in the recent expansion of immigrant or refugee situations. Moreover, with this introduction we have shed light on the importance of non-human agency in the processes of perceiving, interpreting and producing contemporary ritual landscapes. The notion of 
'ritual landscape' presented and debated in this special issue - as the locus of relationships between different human and non-human actors - might serve as a useful analytical concept for ethnographies carried out within many different ritual locations. We argue that ways of perceiving landscapes include a number of material and immaterial aspects indicated by ways of moving through landscapes and interacting with different subjects that come to inhabit the world, creating relations and producing agentive ensembles and complexes.

\section{REFERENCES}

Ball, Christopher. 2014. On Dicentization. - Journal of Linguistic Anthropology 23 (2): 151-173. DOI: https://doi.org/10.1111/jola.12046.

Bateson, Gregory. 1963. A Social Scientist Views the Emotions. - Expressions of the Emotions in Man, edited by Peter Knapp. New York, NY: International University Press, 230-236.

Bateson, Gregory. 1972. Steps to an Ecology of Mind. London: Paladin Books.

Benedito, Julio Cezar. 2006. Religiões e religiosidades populares, o conflito religioso e a simbiose de ritos e performances entre neopentecostalismo e afro-brasileiros. - Universitas Humanística 6: 231-253.

Berthomé, François and Michael Houseman. 2010. Rituals and Emotions. - Religion and Society 1: $57-75$.

Blanes, Ruy and Diana Espírito Santo. 2014. Introduction. - The Social Life of Spirits, edited by Ruy Blanes and Diana Espírito Santo. Chicago, IL: The University of Chicago Press, 1-32.

Durkheim, Emil. 1947 [1912]. Elementary Forms of Religious Life. Glencoe: Free Press.

Caraveli-Chaves, Anna. 1980. Bridge Between Worlds: The Greek Women's Lament as Communicative Event. - Journal of American Folklore 93 (374): 129-51. DOI: https://doi.org/10.2307/541009.

Casey, Edward. 1993. Getting back into Place. Bloomington, IN: Indiana University Press.

Casey, Edward. 1997. The Fate of Place: A Philosophical History. Berkeley, CA: University of California Press.

Coole, Diana and Samantha Frost, eds. 2010. New Materialism: Ontology, Agency and Politics. Durham: Duke.

Descola, Philippe. 2013. Landscape Forms. Lecture, Collége de France, Paris, March 6. http://www. college-de-france.fr/site/en-philippe-descola/course-2013-03-06-14h00.htm (accessed January 3, 2017).

Goldman, Marcio. 2011. An Afro-Brazilian Theory of a Creative Process: An Essay in Anthropological Symmetrization. - Challenge of Epistemology: Anthropological Perspectives, edited by Christina Toren and João de Pina Cabral. New York, NY: Berghahn, 108-129.

Halloy, Arnaud. 2013. Objects, Bodies and Gods: A Cognitive Ethnography of an Ontological Dynamic in the Xangô Cult. - Making Spirits: Materiality and Transcendence in Contemporary Religions, edited by Espírito Santo and Nico Tassi. New York, NY; London: Tauris, 133-158.

Hastrup, Kirsten. 1998. A Place Apart. Oxford: Clarendon Press.

Henare, Amiria; Martin Holbraad and Sari Wastell. 2007. An Introduction. - Thinking Through Things: Theorizing Artefacts Ethnographically, edited by Amiria Henare, Martin Holbraad and Sari Wastell. New York, NY: Routledge, 1-31.

Hirsch, Eric and Michael O'Hanlon. 1995. Anthropology of Landscape: Perspectives on Place and Space. Oxford: Clarendon Press.

Holbraad, Martin. 2011. Can Things Speak? - Open Anthropology Cooperative Press. http://openanthcoop.net/press/2011/01/12/can-the-thing-speak/ (accessed May 22, 2016). 
Holbraad, Martin. 2012. Things as Concepts: Anthropology and Pragmatology. - Savage Objects, edited by Godofredo Pereira. Lissabon: Guimarães, 17-30.

Honkasalo, Marja-Liisa. 2016. After Sacrifice. Words and Deeds for Protection and Cure. - Suomen Antropologi: Journal of the Finnish Anthropological Society (Special Issue: Ritual Intimacy - Ritual Publicity: Engaging with Plurality) 41 (4): 29-45.

Houseman, Michael. 2006. Relationality. - Theorizing Rituals: Issues, Topics, Approaches, Concepts, edited by Jens Kreinath, Jan Snoek and Michael Stausberg. Leiden: Brill, 413-428.

Houseman, Michael and Carlo Severi. 1998. Naven or the Other Self: A Relational Approach to Ritual Action. Boston, MA: Bill.

Hubert, Henry and Marcel Mauss. 1964 [1899]. Sacrifice. Its Nature and Functions. Chicago, IL: University of Chicago Press.

Ingold, Tim. 1993. The Temporality of the Landscape. - World Archaeology 25 (2): 152-174. DOI: https://doi.org/10.1080/00438243.1993.9980235.

Ingold, Tim. 2000. The Perception of the Environment: Essays on Livelihood, Dwelling and Skill. London; New York, NY: Routledge. DOI: https://doi.org/10.4324/9780203466025.

Ingold, Tim. 2009. Against Space: Place, Movement, Knowledge. - Boundless Worlds. An Anthropological Approach to Movement, edited by Peter Wynn Kirby. New York, NY; Oxford: Berghahn Books, 29-43.

Ingold, Tim and Gisli Pálsson, eds. 2013. Biosocial Becomings: Integrating Social and Biological Anthropology. Cambridge; New York, NY: Cambridge University Press.

Kelly, John D. and Martha Kaplan. 1990. History, Structure, and Ritual. - Annual Review of Anthropology 19: 119-150. DOI: https://doi.org/10.1146/annurev.an.19.100190.001003.

Kirby, Peter Wynn. 2009. Lost in 'Space': Anthropological Approach to Movement. - Boundless Worlds. An Anthropological Approach to Movement, edited by Peter Wynn Kirby. New York, NY; Oxford: Berghahn Books, 1-27.

Latour, Bruno. 2005. Reassembling the Social. Oxford: Oxford University Press.

Latour, Bruno. 2012. An Inquiry into the Modes of Existence. Cambridge: Harvard University Press.

Lambek, Michael. 1999. Ancestors, Power and History in Madagascar. Edited by Karen Middleton. Leiden: Brill.

Lévi-Strauss, Claude. 1958. Anthropologie structurale. Paris: Plon.

Lundell, Eleonora. 2010. Rahat ja Henki: tutkimus kääntymisestä uushelluntailaiseen Igreja Universal do Reino de Deus -kirkkoon Rio de Janeirossa. A Master Dissertation. University of Helsinki, Department of World Cultures.

Lundell, Eleonora. 2016. Exú's Work: The Agency of Ritual Objects in Southeast Brazilian Umbanda. - Journal of Ethnology and Folkloristics 10 (1): 43-69. DOI: https://doi.org/10.1515/ jef-2016-0003.

Massey, Doreen. 1994. Space, Place, and Gender. Minneapolis, MN: University of Minnesota Press.

Massey, Doreen. 2005. For Space. Los Angeles, CA: Sage.

Metcalf, Peter. 1991. Celebrations of Death. Cambridge: Cambridge University Press. DOI: https:// doi.org/10.1017/CBO9780511803178.

Moore, Jerry D. 2004. The Social Basis of Sacred Spaces in the Prehispanic Andes: Ritual Landscapes of the Dead in Chimú and Inka Societies. - Journal of Archaeological Method and Theory 11 (1): 83-124. DOI: https://doi.org/10.1023/B:JARM.0000014348.86882.50.

Morphy, Howard. 1991. Ancestral Connections. Art and Aborginal System of Knowledge. Chicago, IL: The University of Chicago Press.

Myers, Fred. 2013. Emplacement and Displacement: Perceiving the Landscape Through Aboriginal Australian Acrylic Painting. - Ethnos 78 (4): 435-63. DOI: https://doi.org/10.1080/0014184 4.2012.726635.

Obeyesekere, Gananath. 1981. Medusa's Hair. An Essay On Personal Symbols And Religious Experience. Chicago, IL: The University of Chicago Press. 
Pérez, Patrick. 2012. Elements of Amerindian Landscape: The Arizona Hopi. - Landscapes beyond Land, edited by Arnar Árnason, Nicolas Ellison, Jo Vergunst and Andrew Whitehouse. London: Berghahn, 83-97.

Robb, John G. 1998. The ‘Ritual Landscape' Concept in Archaeology: A Heritage Construction. Landscape Research 23 (2): 159-174. DOI: https://doi.org/10.1080/01426399808706533.

Robbins, Joel. 2009. Pentecostal Networks and the Spirit of Globalization. - Social Analysis 53: 55-66. DOI: https://doi.org/10.3167/sa.2009.530104.

Robbins, Joel and Johanna Sumiala. 2016. Ritual Intimacy - Ritual Publicity: Revisiting Ritual Theory and Practice in Plural Societies. - Suomen Antropologi: Journal of the Finnish Anthropological Society (Special Issue: Ritual Intimacy - Ritual Publicity: Engaging with Plurality) 41 (4): $1-5$.

Sansi, Roger. 2013. We Worship Nature: The Given and the Made in Brazilian Candomblé. - Making Spirits: Materiality and Transcendence in Contemporary Religions, edited by Diana Espírito Santo and Nico Tassi. New York, NY; London: Tauris, 81-104.

Santos-Granero, Fernando. 1998. Writing History into the Landscape: Space, Myth and Ritual in Contemporary Amazonia. - American Anthropologist 25 (2): 128-148. DOI: https://doi. org/10.1525/ae.1998.25.2.128.

Taussig, Michael. 2009. What Color is the Sacred? Chicago, IL: University of Chicago Press. DOI: https://doi.org/10.7208/chicago/9780226789996.001.0001.

Tilley, Christopher. 1994. A Phenomenology of Landscape: Places, Paths, and Monuments. Oxford: Berg.

Turner, Victor. 1967. The Forest of Symbols. Aspects of Ndembu Ritual. Ithaca: Cornell University Press.

Turner, Victor. 1977. Sacrifice as Quintessential Process: Prophylaxis or Abandonment? - History of Religions 16 (3): 189-215. DOI: https://doi.org/10.1086/462765.

Virtanen, Pirjo Kristiina. 2011. Constancy in Continuity: Native Oral History, Iconography and the Earthworks of the Upper Purus. - Ethnicity in Ancient Amazonia: Reconstructing Past Identities from Archaeology, Linguistics, and Ethnohistory, edited by Alf Hornborg and Jonathan D. Hill. Boulder, CO: University Press of Colorado, 279-298.

Virtanen, Pirjo Kristiina. 2015. Fatal Substances: Apurinã's Dangers, Movement, and Kinship. - Indiana 32: 85-103.

Virtanen, Pirjo Kristiina and Sanna Saunaluoma. Forthcoming. Visualization and Movement as Configurations of Human-non-human Engagements: The Geometric Earthwork Landscapes of the Upper Purus, Brazil. - American Anthropologist.

Wright, Robin. 2013. Mysteries of the Jaguar Shamans of the Northwest Amazon. Lincoln, NE: University of Nebraska Press. 